\title{
PENERAPAN KAIDAH LA NAHYU PADA JUZ 30: Analisis Muhammad Khalid Al-Sabith
}

\author{
Dindin Moch Saepudin ${ }^{1}$ \\ ${ }^{1}$ Program Pascasarjana S2 UIN Sunan Gunung Djati Bandung \\ email:mohsaepudin@gmail.com
}

Received: 27/12/2018, Accepted: 07/05/2019, Published: 09/05/2019

\begin{abstract}
Usul experts both in Fiqh and Tafsir there are differences in understanding about alnahyu which has an intrinsic meaning namely al-tahrim (التحريم) or meaning majazi, which has several meanings such as du'a (الدعاء), iltimas (الإنماس), irshad (الإلتمشاد), dawam (الْدوام), bayan al-'aqibah (بيان العقبه), al-yais (اليأس)), tamanni (التمني)), tahdid,

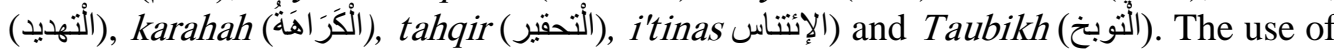
Nahyu is more emphasized in the Shari'a-Islamic and legal operations, while Nahyu's meaning on the issue of faith, faith and morals is still rarely done, therefore the author attempts to analyze La Nahyu with Muhammad Khalid al-Sabith's rule of approach in the work of Qawaid al-Tafsir in Juz 30 which is a letter of Makiyyah, which recurs 29 times in Surat Al-Naba: 24 (2), 35 (2), 37.38, Al-Infitar: 19, Al-Inshiqaq: 20, 21, Al'Ala: 6, 13 (2), Al-Ghashiyyah: 7 (2), 11, 17, Al-Fajr: 17, 18, 25,26, Al-Balad : 11, AlShams: 15, Al-Lail: 15, Al-Duha: 9,10, Al-'Alaq: 19, Al-'Adiyat: 9, Al-Maun: 3, AlKafirun: 2. The results of the study show that the use of La Nahyu approach from rule of Muhammad Khalid al-Sabith's are: the one rule is used in 6 verses, four rules in 17 verses, and the fifth rule in 5 verses, while the La Nahyu meaning is At-Tahrim repeated 4 times, while the meaning of majazi repeats 25 times with the meaning of taubikh (توبخ) 4 times , Bayan al-'Aqibah (بيان العقبه) 15 times, al-yais (اليأس) 1 time, dawam (الْدوام) 2 times, tahqir (الْحقير) 2 time, and irshad (الإرشاد) This shows that the verses of Makiyyah do not address the issue of Shari'a law but emphasize faith, universal faith and morality,
\end{abstract}

Keyword: la nahyu, tafsir rules, qawaid al-tafsir, Muhammad Khalid al-Sabith

\section{ABSTRAK}

Para ahli Uhsul baik dalam fiqih maupun tafsir terdapat perbedaan paham mengenai al-nahyu yang bermakna hakiki yaitu al-tahrim (التحريم) atau bermakna majazi, yang mempunyai beberapa makna seperti doa (الدعاء), iltimas (النْرشاد), irrshad (النماد), dawam (الْدوام), bayan al-'aqibah (بيان العقبه), al-yais (اليأس), tamanni (التمنير), tahdiid,

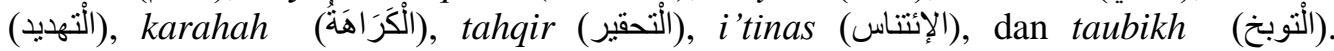
Penggunaan nahyu lebih ditekankan pada syariat-syariat Islam dan operasional hukum. Sedangkan pemaknaan Nahyu pada masalah akidah, keimanan dan moral masih jarang dilakukan, oleh karena itu penulis berupaya menganalisis La Nahyu dengan pendekatan kaidah Muhammad Khalid Al-Sabith dalam karya Qawaid Al- 
Tafsir pada Juz 30 yang merupakan surat Makiyyah, yang terulang 29 kali pada Surat Al-Naba: 24 (2), 35 (2), 37, 38, Al-Infithar: 19, Al-Insyiqaq: 20, 21, Al-'Ala: 6, 13 (2), Al-Ghashiyah: 7 (2),11, 17, Al-Fajr: 17, 18, 25, 26, Al-Balad: 11, Al-Syams: 15, AlLail: 15, Al-Dhuha: 9, 10, Al-'Alaq: 19, Al-'Adiyat: 9, Al-Ma'un: 3, dan Al-Kafirun: 2, selain itu kelebihan. Hasil penelitian menujukkan bahwa penggunaan kaidah Nahyu Usman Bin sabit yaitu kaidah satu digunakan pada 6 ayat, kaidah empat pada 17 ayat, dan kaidah lima pada 5 ayat, sedangkan makna La Nahyu yang bermakna hakiki terulang 4 kali yang bermakna al-tahrim, sedangkan makna majazi terulang 25 kali dengan makna taubikh 4 kali, bayan al-'aqibah 15 kali, al-ya'is (اليأس)1 kali, aldawam (الْدوام) 2 kali, al-tahqir (الْتحقير) 2 kali, dan al-irsyad (الإرشاد) 2 kal terebut menunjukkan bahwa ayat-ayat Makiyyah tidak menyinggung masalah hukum syariat tetapi menekankan kepada keimanan, akidah dan moral universal.

Kata Kunci: la nahyu, kaidah tafsir, qawaid al-tafsir, Muhammad Khalid Al-Sabithi.

\section{A. PENDAHULUAN}

Kaidah Usul Fiqih merupakan instrumen yang mesti diketahui dalam menafsirkan Al-Qur'an, karena kaidahkaidah tersebut membedah maknamakna dari Al-Qur'an. Bahkan para Mufasir menetapkan syarat-syarat yang ketat terhadap interpretasi Al-Qur'an, baik dari tokoh klasik ataupun kontemporer selalu memasukkan kaidah Usul Fiqih sebagai syarat yang harus dimiliki oleh seorang mufasir, seperti pendapat dari Jalaluddin Al-Suyuthi yang menetapakan lima belas ilmu yang harus dikuasai oleh seorang mufasir yaitu ilmu bahasa arab, nahw, saraf, ishtiqaq, al-ma'ani, al-bayan,al-badi', qira'ah, usuluddin, usul fiqh, asbab alnuzul, nasikh wa Mansukh,Fikh, hadits dan ilmu muhibbah. ${ }^{1}$

1 Jalaluddin Al-Suyuthi. (1429). Al-Itqan fii Ulumil Qur'an. 1 ed., Jami Al-Huquq Mahfudzat li Nasir. hlm. 771-772.
Salah satu kaidah yang menjadi perdebatan dalam implikasi Ibadah adalah Amr dan Nahyu, karena Amr merupakan perintah sedangkan Nahyu adalah larangan konsekuensi dari kaidah Amr dan Nahyu tersebut dapat merujuk kepada perbuatan yang dihukumkan wajib, sunnah, haram makruh, dan mubah. $^{2}$

Kaidah Amr dan Nahyu selain masuk pada ranah Usul Fiqh masuk pula pada ranah Qawa'id Al-Tafsir yang mempunyai fungsi yang sama. $^{3}$ Perbedannya adalah Usul Fiqh berdiri sendiri sebagai disiplin ilmu, sedangkan Qawaid Tafsir salah satu sumber yang

${ }^{2}$ A Hanafie. (1981). Usul Fiqh. Jakarta: 8 ed. Widjaya. hlm. 21-24.

${ }^{3}$ Makna Usul Fiqh ialah berupaya untuk menyelidiki dallil syara serta mengetahui bagaiamana dalil syara tersebut menunjukkan hukum terhadap mukallaf, sedangkan makna Qawaid Al-Tafsir ialah kaidah-kaidah yang membantu mufasir dalam menarik makna ataupun pesan-pesan Al-Qur'an. 
digunakan ialah Usul Fiqh. ${ }^{4}$ Walaupun begitu para ahli Usul baik dalam Fiqih maupun Tafsir terdapat perbedaan paham mengenai Al-Nahyu bermakna hakiki yaitu Al-Tahrim atau Majazi, yang mempunyai beberapa makna. Mereka bersepakat bahwa pemaknaan Al-Tahrim yang menuntut peninggalan terhadap suatu perbuatan merupakan $\mathrm{Al}$ Haqiqah yang tidak perlu ada qarinah, sedangkan pemaknaan yang lain merupakan gaya bahasa al-majaz yang membutuhkan qarinah dan menghendaki makna yang lain, yang dapat dipahami dari susunan kalimat serta kondisi dan situasinya seperti bermakna Doa (الدعاء), al-iltimas (إلتماس), al-irsyad (الإرشاد), Al-Dawam (الدوام), al-bayan al-’aqibah (بيان العقبه) , Al-Ya'is (اليأس), al-tamanni (التنمي), altahdiid, (التهديد), al-karahah (الْكَرَا اهَةُة), altahqir (التحقير), al-i'tinas (الإيتناس) dan altaubikh (التوبخ) yang dalam penerapannya selelu berbeda.

Oleh karena penulis menggunakan pendekatan kaidah Al-Nahyu Muhammad Khalid Al-Sabt pada Juz 30 untuk menentukan makna Hakiki dan Majazi. Alasan menggunakan pendekatan Muhammad Khalid Al-Sabt

\footnotetext{
${ }^{4}$ Syamsuri. (2011). Pengantar Qawaid AlTafsir: Sulesana, 6(2). hlm. 94.
}

dalam karyanya karena mempunyai beberapa kelebihan di antaranya merupakan seorang ulama kontemporer serta dalam kaidah tafsir yang ditulisnya mempunyai karakteristik dengan menjelaskan metode yang diambil serta bagaimana kaidah tersebut diformulasikan dan menjelaskan perbedaan-perbedaan para ulama dalam memahami suatu kaidah. Seabagaiamana dijelaskan dalam metode yang digunakan, yaitu dua belas langkah mengetahu maqasid, al-ta'rifat, qawa'id, al-ihalat, taudih al-qa'idah, tatbiqat al-qa'ida, tajamah al-a'lam, 'azaut al-Ayat al-quraniyyah, hadits wa athat, al-swahid al-sa'riyyah, fussirat al-kalimat al-ghamidah dan Ijtihd. $^{5}$ Sedangkan Pemilihan Juz 30 karena merupakan surat-surat yang merujuk pada aqidah dan keimanan yang merupakan ayat-ayat Makiyyah, yang sangat jarang dikaji dalam pemaknaan Qawaid Al-Tafsir mengenai La Nahyu, hal tersebut terlihat dari penelitianpenelitian sebelumnya seperti Penerapan Al-Amr, Al-Nahy Dan AlIbahah Sebagai Kaidah Penetapan Hukum karya Kartini yang mendeskripsikan Al-Amr, Al-Nahyu

\footnotetext{
${ }^{5}$ Khalid Utsman Al-Sabt. (1421). Qawaid Al-Tafsir. Dar Ibn 'Affan. hlm. 6-10.
} 
dan Ibahah dalam pandangan Usul Fiqh untuk menentukan operasional hukum dalam Al-Qur'an dan Al-Sunnah. ${ }^{6}$

Lalu artikel mengenai kaidahkaidah tafsir berkaitan dengan kaidah Usul Fiqh Menurut Khalid Utsman AlSabt karya Ismardi ${ }^{7}$ yang menjelaskan mengenai kaidah-kaiadah dan contohcontoh al-amm al-khash, al-mutlaq almuqayyad, dan al-mantuq al-mafhum yang dikemukakan oleh Khalid Utsman Al-Sabt. ${ }^{8}$ Artikel mengenai kaidahkaidah memahami Al-Amr dan AlNahy: Urgensitasnya dalam Memahami Al-Qur'an karya Siti Fahimah yang mendeskripsikan tentang pentingnya seorang ulama menggunakan kaidahkaidah Usul Fiqh dalam menafsirkan Al-Qur'an serta menjelaskan pula kaidah-kaidah amr dan Nahyu dalam mengambil hukum. ${ }^{9}$

Oleh sebab itu perlu diketahui bagaiamana makna La Nahyu pada Juz

${ }^{6}$ Kartini. (2016). Penerapan Al-Amr, AlNahy dan Al-Ibahah Sebagai Kaidah Penetapan Hukum. Jurnal Al- 'Ad, 9(1). hlm. 9.

7 Siti Fahimah. (2018). Kaidah-Kaidah Memahami Amr dan Nahy: Urgensitasnya Dalam Memahami Al-Qur'an. Al Furqan: Jurnal Ilmu Al Quran dan Tafsir, 01(1). hlm. 12.

${ }^{8}$ Ismardi. (2014). Kaidah-Kaidah Tafsir Berkaitan Dengan Kaidah Ushul Menurut Khalid Utsman Al-Sabt: Kajian Terhadap Kaidah Al-Amm-Al-Khass, Al-Mutlaq-AlMuqayyad, dan Al-Mantuq-Al-Mafhum. Jurnal An-Nida': Jurnal Pemikiran Islam, 39(2). hlm. 59-60.

${ }^{9}$ Siti Fahimah. (2018). hlm. 12.
30 dengan pendekatan Kaiadah Tafsir karya Muhammad Khalid Al-Sabt, sehingga dapat memeberikan panduan terhadap makna Nahyu dalam keimanan apakah merujuk kepada $A t$ Tahrim atau pun pemaknaan yang lain, sehingga selain mengetahui makna tersebut dapat meningkatkan pula aqidah bahkan keimanan umat Islam terhadap apa-apa yang telah Allah S.W.T., tidak hanya sebatas pada syariat dalam pelaksanaan ibadah.

Penggunaan Nahyu pada Juz 30 terulang 28 kali pada Surat Al-Naba': 24 (2), 35(2), 37, 38, Al-Infithar: 19, AlInsyiqaq: 20, 21, Al-'Ala: 13 (2), AlGhasyiyah: 7(2), 11, 17, Al-Fajr: 17, 18, 25,26, Al-Balad: 11, Al-Syams: 15, AlLail: 15, Al-Duha: 9,10, Al-'Alaq: 19, Al'Adiyat:9, Al-Ma'un: 3, Al-Kafirun: 2.

\section{B. PEMBAHASAN}

\section{Pengertian An-Nahyu}

Nahyu merupakan masdar dari yang berarti melarang atau mencegah. $^{10}$ Secara bahasa ialah larangan sebagaimana definisi yang diungkapkan di Lisan Al- 'Arab

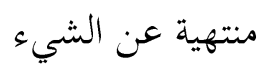

10 Ahmad. W. Munawwir. (1997). AlMunawir. Pustaka Praja. hlm. 734. 
"Larangan dari segala sesuatu",, makna larangan sendiri dapat diartikan yaitu satu perintah yang tidak diperbolehkan dilakukan. Secara istilah makna Nahyu ialah lafal yang digunakan oleh yang lebih tinggi kedudukannya untuk menuntut kespada yang lebih rendah kedudukannya agar meninggalkan apa yang telah dilarangnyan. ${ }^{12}$ sebagaimana definisi yang dikemukakan oleh Abdul Wahab Khalaf:

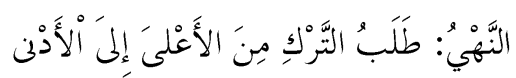

Adapun definisi lain yaitu menuntut agar tidak melaksanakan sesuatu baik yang bersifat konkrit ataupun abstrak, yang derajtnya yang melarangnya lebih tinggi, ${ }^{13}$ sebagaimana definisi yang dikemukakan oleh Abdurrahman Hasan:

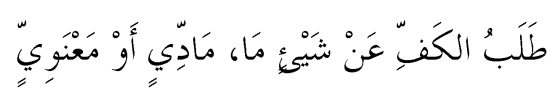

Sehingga secara sederhana bahwa Nahyu adalah menuntut berhenti melakukan suatu perbuatan oleh pihak

${ }^{11}$ Ibnu Mandzur. Lisan Al- 'Arabiyya. Dar Al-Ma'arif. hlm. 4564.

12 Abdul Jahhab Khallaf. (1991). KaidahKaidah Hukum Islam (Ilmu Ushul Fiqih. Diterjemahkan Noer Iskandar Al-'Arsany dan Moh. Tolchah Mansuer. Rajawali Per. hlm. 326.

13 Abdurrahman Hasan Habnakah AlMaidaniy. (1996). Al-Balagat Al-Arabiyah: Ususuha wa 'Ulumuha wa Fununuha. Vol. 1, Dar Al-Qalam. hlm. 228. yang lebih tinggi kepada pihak yang lebih rendah baik bentuknya abstrak ataupun konkrit.

\section{Bentuk An-Nahyu}

Penggunaan Nahyu terdapat dua bentuk yang selalu digunakan yaitu:

a. Menggunakan la nahyu yang setelahnya ada fi'il Mudhari, seperti wazan تفعل janganlah atau menunjukkan, ${ }^{14}$ seperti contoh dalam ayat AlQur'an:

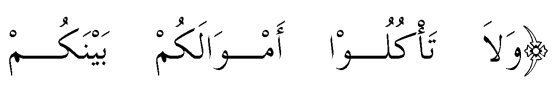

$$
\text { بالَْاطِلِ }
$$

Dan jangan engkau memakan harta saudaramu dengan cara batil.” (Q.S. Al-Baqarah: 188)

b. Bentuk lafal yang menunjukkan bentuk pelarangan, seperti lafal أنرك dan حرم, نهي

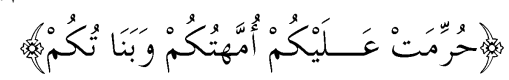

"Diharamkan bagi kamu ibu-ibumu dan anak-anak perempuanmu". (Q.S. Al-Nisa: 23)

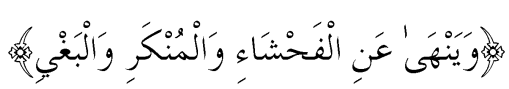

"Dan Allah melarang dari perbuatan keji, kemungkaran dan permusuhan.” (Q.S. Al-Nahl: 90)

${ }^{14}$ Abdul Karimi Ibn 'Ali Ibn Muhammad Al-Namlah. (1420). Al-Mazhab fi 'Ilmi Usul Fiqhi Al-Muqarin. Vol. 3, Maktabah Rashada. hlm. 1434. 


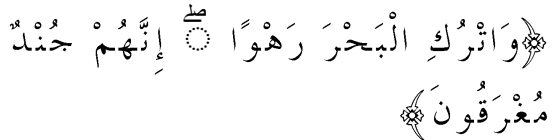

"Dan biarkanlah laut itu tetap terbelah. Sesungguhnya mereka adalah tentara yang akan ditenggelamkan". (Q.S. Ad-

Dukhan: 24)

\section{Makna An-Nahyu}

Selain bermakna larangan, bentuk Nahyu juga mempunyai makna-makna lain, karena adanya pergeseran pengungkapan, seperti makna Doa (الدعاء), Iltimas (الإلتماس), Irsyad (الدوام), Dawam al'Aqibah (البيان العقبه), al-yais (اليأس), Tamanni (التمني), Tahdiid, (التهديد), Karahah (الْكَرَاهَةُّئ), Tahqir (التحقير), I'tinas (الإِتناس) dan Taubikh (التوبخ).

a. Do'a (الدعاء) bermakna bahwa melarang ataupun menolak dengan doa dari derajat rendah kepada derajat yang lebih tinggi. ${ }^{16}$ Seperti firman Allah S.W.T.:

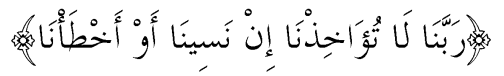

"Ya Tuhan kami, janganlah Engkau hukum kami, jika kami lupa atau

15 Zuhri dan Ahmad Chumaidi. (1994). Terjemah Jawahirul Balaghah. Surabaya: 1 ed., Mutiara Ilmu. hlm. 88.

16 Al-Jami'ah Al-Islamiyyah bin Allmadinah Al-Nabawi. Mudzakkirah Usul Fiqih. Mauqi' Al-Jami'ah 'ala Iftirafat. hlm. 20. kami bersalah." (Q.S. Al-Baqarah: 286)

b. Iltimas (الإلتماس) dapat diartikan ajakan atau tawaran, ${ }^{17}$ seperti ajakan seseorang kepada teman sebaya.

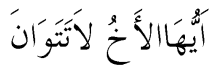

"Hai saudara, janganlah engkau bersantai-santai."

c. Irshad (الإرشاد) yang berarti petunjuk terhadap sesuatu yang baik, ${ }^{18}$ seperti firman Allah S.W.T.:

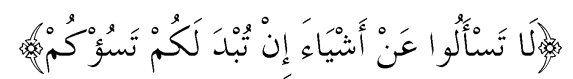

"Janganlah kamu menanyakan kepada nabimu hal-hal yang jika diterangkan kepadamu niscaya menyusahkan kamu." (Q.S. AlMaidah: 101)

d. Dawam (الدوام) yang berarti untuk larangan ataupun penolakan terhadap sesuatu yang ada atau semestinya yang masih tetap atau pun terus berlangsung. ${ }^{19}$ seperti firman Allah S.W.T.:

每 "Dan janganlah sekali-kali kamu (Muhammad) mengira bahwa

${ }^{17}$ Ali Al-Karim, et al. (2011). Terjemahan Al-Balaaghatul Waadhihah. Bandung: 1 ed., Sinar Baru Algensindo. hlm. 263.

18 Al-Jami'ah Al-Islamiyah bin Allmadinah Al-Nabawi. hlm. 20.

19 Adib Bisri, dan Munwwir A. Fatah. (1999). Kamus Al-Bisri. Pustaka Progressif. hlm. 213. 
Allah lalai dari apa yang diperbuat oleh orang-orang yang zhalim.” (Q.S. Ibrahim: 42)

e. Bayan al-aqibah (بيان العقبه) yang berarti menjelaskan akibat, ${ }^{20}$ seperti firman Allah S.W.T.:

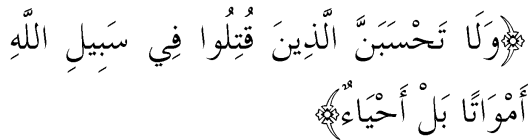

"Dan janganlah kamu mengira bahwa orang-orang yang gugur di jalan Allah itu mati, bahkan mereka itu hidup." (Q.S. Ali'Imran: 169)

f. Al-Yais (اليأس), yang berarti menunjukkan putus harapan ketika menolak ataupun melarang, ${ }^{21}$ seperti firman Allah:

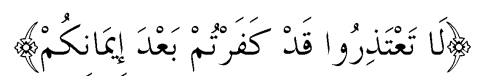

"Tidak usah kamu minta maaf, karena kamu kafir sesudah beriman.” (Q.S. At-Taubah: 66)

g. Tamanni (التمني), yaitu mengharap sesuatu yang diidamkan tetapi sulit tercapai ataupun mustahil didapatkan. seperti:

\section{يَا لَيْلَة الْنأُنْسِ لََ َنْقَضَى}

"Hai malam gembira, janganlah engkau habis!"

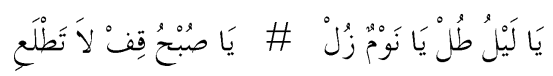

"Hai malam, panjanglah, hai tidur, hilanglah, hai subuh,

\footnotetext{
${ }^{20}$ Siti Fahimah. (2018). hlm. 9.

${ }^{21}$ Siti Fahimah. (2018). hlm. 9.
}

berhentilah, janganlah engkau terbit."

h. Tahdiid, (التهديد) yang berarti ancaman $^{22}$ seperti firman Allah S.W.T. pada Surat Al-Tahrim: 7:

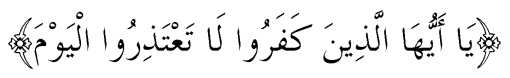

Hai orang-orang kafir, janganlah kamu mengemukakan uzur pada hari ini.

i. Karahah (الْكَرَاهَةُّ) menjukkan makna kemakruhan(A Hanafie 45), ${ }^{23}$ seperti:

$$
\text { لا تصلو ا في اعطان الأبل }
$$

"janganlah salat dikandang unta"

j. Taubikh (التوبخ) yang berarti menunjukkan makna menegur, seperti:

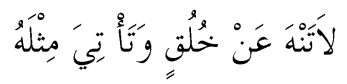

"Janganlah engkau melarang suatu budi, padahal engkau melakukan semisalnya."

k. I'tinas (الإنتناس) yang berarti menghibur atau memberikan ketenangan, ${ }^{24}$ seperti firman Allah S.W.T., pada surat Al-Taubah: 40:

$$
\text { 禹 }
$$

"Janganlah kamu berduka cita, sesungguhnya Allah bersama kita."

\footnotetext{
${ }^{22}$ A Hanafie. (1981). hlm. 46.

${ }^{23}$ A Hanafie. (1981). hlm. 45.

24 Mahmud Yunus. (1989). ArabIndonesia. Mahmud Yunus Wa Dzurriyah. hlm. 197.
} 
i. Tahqir (التحقير) menunjukkan makna untuk menghina, ${ }^{25}$ seperti:

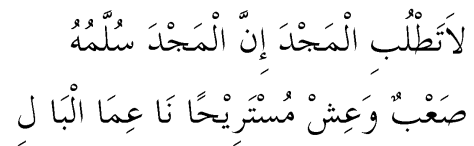

"Janganlah anda mencari kemuliaan, karena kemuliaan itu tangganya, sungguh sulit dan hiduplah anda, secara tenang lagi nikmat hatinya."

\section{Kaidah}

Terdapat beberapa kaidah Nahyu untuk memahami bagaiamana redaksi dan makna yang ditujukkan. Menurut Khalid bin utsman As-sabt yaitu:

a. Nahyu menghendaki atau menunjukkan haram, segera untuk dilarangnya, kecuali ada qarinahqarinah tertentu, ${ }^{26}$ sebagaimana ungkapan kaidahnya:

النهي يقتضي التحريم و الفوروالدوم الال لقرينة

Lafazh Nahyu menghendaki tuntutan larangan secara kekal (dawam) dan spontan (fauran). Sebab yang di tuntut itu (larangan) tidak dapat terwujud apabila tuntutan larangan itu bersifat kekal. Maksudnya bahwa setiap kali jiwa seorang mukallaf mendorongnya untuk melakukan yang terlarang, maka setiap kali itu pula

\footnotetext{
${ }^{25}$ Mahmud Yunus. (1989). hlm. 106.

${ }^{26}$ Khalid Utsman Al-Sabt. (1421). Qawaid Al-Tafsir. Dar Ibn 'Affan. hlm. 509.
}

Nahyu menuntut dia untuk meninggalkannya. Karena itu, pengulangan larangan termasuk kaidah yang penitng agar tuntutan dari Nahyu dapat terwujud. Demikian juga dengan tuntutan terhadap spontinitas dalam mentaati larangan. Sebab larangan atas suatu perbuatan adalah berarti mengharamkan perbuatan itu, lantaran ada bahayanya. Karenanya, larangan itu mesti menuntut spotanitas. Melakukan ketataan atas suatu larangan secara spontan dan berkesinambungan adalah temasuk hal-hal yang dituntut oleh Nahyu. Adapun Qarinah dapat merjuk kepada lughawi atau pun naql (yang menunjukkan makna pengharaman). ${ }^{27}$ Seperti dalam Q.S. Al-An'am Ayat 151:

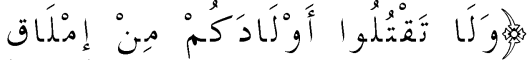

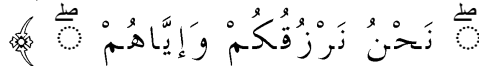
Al-An'am: 151)

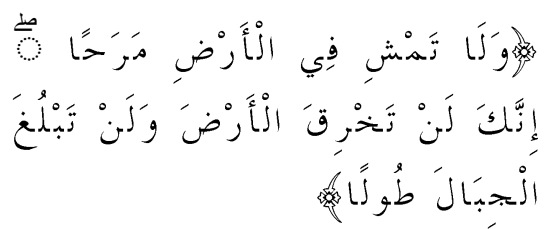

"Dan janganlah kamu berjalan di muka bumi ini dengan

\footnotetext{
27 Khalid Utsman Al-Sabt. (1421). hlm.
} 510. 
sombong,

karena

Sesungguhnya kamu sekali-

kali tidak dapat menembus

bumi dan sekali-kali kamu

tidak akan sampai setinggi

gunung. (Q.S. Al-Isra’: 37)

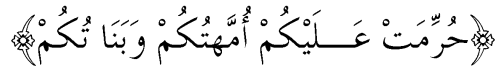

"Diharamkan bagi kamu ibuibumu dan anak-anak perempuanmu." (Q.S. Al-

Nisa': 23)

b. Jika Allah melarang sesuatu, maka Ia melarang sebagiannya juga. Dan jika Allah memerintahkan sesuatu, maka Ia memerintahkan secara

keseluruhannya. Sebagaimana kaidahnya :

$$
\text { بعضه , و واذ أمر بشيء السارع عن شيء , في عن أمر أبجميعه }
$$

Contoh :

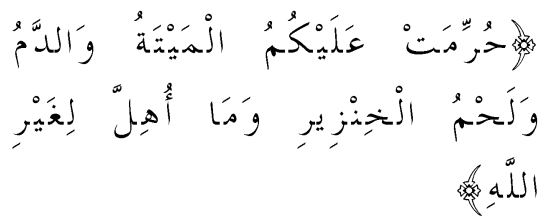

"Diharamkan bagimu (memakan) bangkai, darah, daging babi, (daging hewan) yang disembelih atas nama selain Allah". (Q.S. AlMa'idah: 3)

Namun sebagian larangan dapat pengecualian (istisna) jika ada dalil yang kuat untuk menunjukkan hal tersebut ${ }^{28}$ seperti:

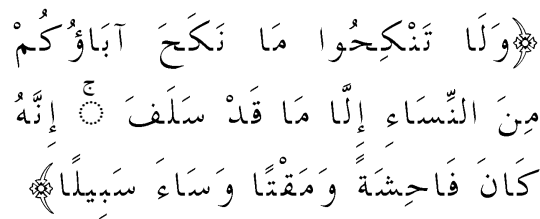

"Dan janganlah kamu nikahi wanita-wanita yang telah dinikahi oleh ayahmu, terkecuali pada masa yang telah lampau. (Q.S. Al-Nisa':

c. Maksud insya'i ${ }^{29}$ menggunakan bentuk khabar30 lebih jelas penyampaiannya dari pada menggunakan sighat insyai itu sendiri, ${ }^{31}$ sebagaimana ungkapan kaidahnya:

إيراد الإنشاء بصيغةالخبر أبلغ من إيرده بصيغة الإنشاء

Seperti contoh:

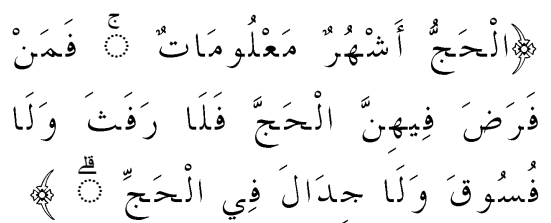

"Musim) haji adalah beberapa bulan yang dimaklumi,

${ }^{28}$ Khalid Utsman Al-Sabt. (1421). hlm. 512.

${ }^{29}$ Insyai merupakan sebuah kalimat yang tidak diketahui benar atau salah yang berbentuk Nida, Tamanni, Tarajji, Istifham, Amr dan Nahyi

${ }^{30}$ Khabar yaitu kalimat yang menunjukkan benar ataupun salah

31 Khalid Utsman Al-Sabt. (1421). hlm. 513. 
Barangsiapa yang menetapkan niatnya dalam bulan itu akan mengerjakan haji, Maka tidak boleh rafats, berbuat Fasik dan berbantah-bantahan di dalam masa mengerjakan haji. (Q.S.

Al-Baqarah: 197)

Pada ayat di atas kalimatnya berbentuk Khabar yang menunjuk kepada La Nafi tetapi maksudnya ialah La Nahyu ${ }^{32}$ Adapula yang merujuk la Nafi kepada fiil mudari seperti:

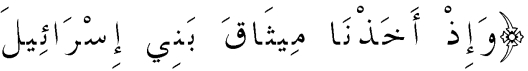

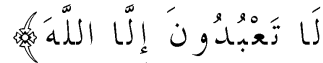

"Dan (ingatlah), ketika Kami mengambil janji dari Bani Israil (yaitu): janganlah kamu menyembah selain Allah (Q.S.

Al-Baqarah: 83)

d. nahy menghendaki fasad, sebagai mana ungkapan kaidahnya:

$$
\text { النهي يقتضي الفساد }
$$

Terdapat perbedaan pendapat ketika tiap-tiap larangan yang ditujunjukkan untuk menghindari keburukan. Salah satu yang menguatkan bahwa tiap-tiap perkara yang menggunakan Nahyu merujuk kepada keburukan dari Ibadah, Muamalah dan

\footnotetext{
32 Khalid Utsman Al-Sabt. (1421). hlm.
} 514.
Aqidah ialah Khalid bin Usmat Al-Sabt dengan mengutip Hadits Nabi:

$$
\text { من أحدث في أمرنا هذا ما ليس فيه فهو رد }
$$

Rasulullah S.A.W. bersabda "setiap perkara yang tidak ada perintah kami, maka ia tertolak"

Sehingga Khalid bin Usmat AlSabt membagi Nahyu yang merujuk kepada fasad, ditinjau dari zatnya dan sifatnya:

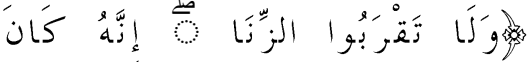

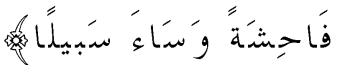
mendekati zina; Sesungguhnya zina itu adalah suatu perbuatan yang keji. dan suatu jalan yang buruk. (Q.S. Al-Isra: 32)

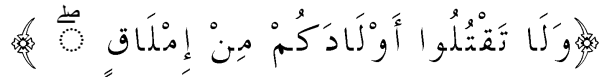

"Dan janganlah kamu membunuh anak-anak kamu karena takut kemiskinan (Q.S. Al-An'am: 151)

Lalu yang merujuk kepada sifatnya:

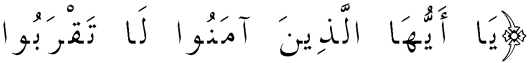

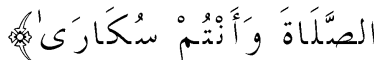

"Hai orang-orang yang beriman, janganlah kamu shalat, sedang kamu dalam Keadaan mabuk, ...(Q.S. AlNisa: 43) 
Namun terdapat pengecualian bahwa Nahyu tidak merujuk kepada keburukan (fasad):

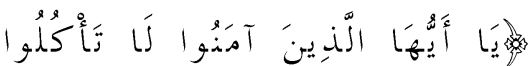

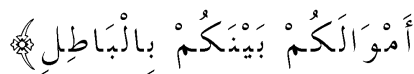

Hai orang-orang yang beriman, janganlah kamu saling memakan harta sesamamu dengan jalan yang batil...(Q.S. Al-Nisa': 29)

e. Nahyu yang diketahui kelaziman yang menunjukkan dilalah Nahyu.

Sebagaiaman kaidah:

$$
\begin{aligned}
& \text { النهي عن الازم أبلغ في الدلالة علي النهي } \\
& \text { عن المعلوم من النهي عنه ابتداء }
\end{aligned}
$$

Seperti contoh:

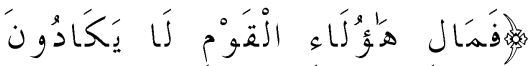

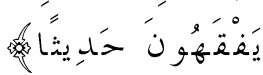

“...Maka mengapa orangorang itu (orang munafik)

Hampir-hampir tidak

memahami pembicaraan

sedikitpun? (Q.S. Al-Nisa': 78)

Pada ayat ini makna Nahyu merupakan mubalagah yang merujuk kepada orang-orang munafik tidak mau menerima Pelajaran dan nasehatnasehat yang diberikan. ${ }^{33}$

\section{Penerapan Kaidah Al-Nahyu pada Juz 30}

33 Khalid Utsman Al-Sabt. (1421). hlm.
Kaidah yang digunakan pada Juz 30 dalam pendekatan Khalid bin Usman Al-Sabt ialah:

a. Kaidah yang pertama yaitu

$$
\text { النهي يقتضي التحريم و الفوروالدوم الا لقرينة }
$$

Kaidah yang pertama yaitu yang menjelaskan bahwa Nahyu menghendaki atau menunjukkan haram, segera untuk dilarangnya, kecuali ada qarinah-qarinah tertentu, (Khalid Utsman Al-Sabt 509) yang terulang 6 kali yaitu pada Surat Al-Naba: 24 (2), Al-Duha: 9,10, Al-'Alaq:19 dan AlKafirun: 2, seperti firman Allah S.W.T. pada Surat Al-Kafirun: 2<smiles>[As]=[W]#[W]</smiles>

Aku tidak akan menyembah apa yang kamu sembah" merupakan larangan Allah kepada Nabi Muhammad S.W.T. untuk tidak mencampuradukan peribadatan orangorang kafir, sehingga ketika umat Islam melanggar hal tersebut termasuk kemusyrikan, dan menjadi dosa besar.

b. Kaidah yang ke empat larangan terhadap fasad dengan kaidah

$$
\text { النهي يقتضي الفساد }
$$

Kaidah keempat ini merujuk kepada larangan Allah S.W.T., kerena merupakan keburukan yang terulang 17 kali pada Surat Al-Insyiqaq: 20, 21, Al510. 
'Adiyat: 9, Al-Naba': 35(2), 37, 38, Al-

'Ala: 13(2), Al-Ghasyiyah: 7 (2), 11, Al-

Fajr: 17, 25, 26, Al-Lail: 15, dan Al-

Ma'un: 3. Seperti pada firman Allah S.W.T.

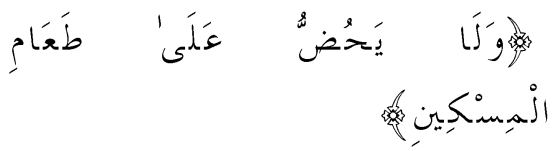

"Dan tidak menganjurkan memberi Makan orang miskin" larangan disini dilakukan oleh orang-orang yang fasik, maka Allah S.W.T., mengingatkan bahwa larangan yang dilakukan oleh mereka merupakan suatu hal yang buruk yang harus dihindari, karena mereka menghardik anak yatim pada ayat 2 "Itulah orang yang menghardik anak yatim,"

c. Kaidah yang ke lima yaitu

$$
\begin{aligned}
& \text { النهي عن الازم أبلغ في الدلالة علي النهي } \\
& \text { عن المعلوم من النهي عنه ابتداء }
\end{aligned}
$$

Kaidah kelima ini merujuk kepada petunjuk Nahyu namun memberikan makna mubalaghah yang terulang 6 kali pada Surat Al-infitar: 19, Al-Shams: 15, Al-Balad: 11, AlFajr: 18, Al-'Ala: 6 dan AlGhasyiyah: 17.

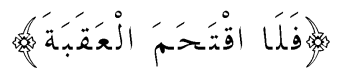

“Tetapi Dia tiada menempuh jalan yang mendaki lagi sukar" La Nahyu disini Allah S.A.W., memperingatkan bahwa orangorang kafir tidak mau menempuh jalan yang mendaki lagi sukar yaitu kebenaran Al-Qur'an dan Rasulullah S.A.W.

\section{Pemaknaan La Nahyu Pada Juz 30}

Terdapat enam makna La Nahyu pada Juz 30 yaitu:

a. Bermakna Al-Tahrim yaitu merupakan pelarangan Allah terhadap segala sesuatu yang terdapat pada Surah Al-Duha: 9, 10, Al-'Alaq: 19. Al-Kafirun: 2. seperti tabel beriktu ini:

\begin{tabular}{|c|c|c|c|}
\hline NO & Surah \& Ayat & Bermakna & Penejelasan \\
\hline 1 & Al-Duha: 9 & 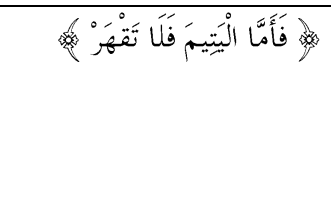 & $\begin{array}{l}\text { larangan Allah terhadap anak } \\
\text { yatim untuk tidak berlaku } \\
\text { sewenang-wenang }\end{array}$ \\
\hline 2 & Al-Duha:10 & 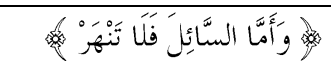 & larangan Allah untuk \\
\hline
\end{tabular}

Tabel 1 Makna Tahrim 


\begin{tabular}{|c|c|c|c|}
\hline & & & $\begin{array}{l}\text { menghardik terhadap orang- } \\
\text { orang yang meminta }\end{array}$ \\
\hline 3 & Al-'Alaq: 19. & 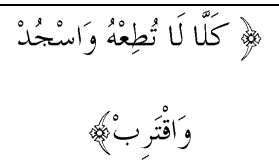 & $\begin{array}{l}\text { Larangan Allah patuh kecuali } \\
\text { kepada Allah S.W.T. }\end{array}$ \\
\hline 4 & Al-Kafirun: 2 & 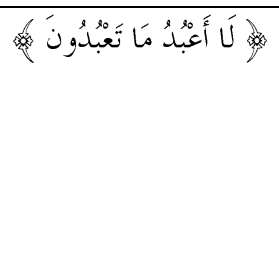 & $\begin{array}{lcc}\text { larangan } & \text { Allah } & \text { yang } \\
\text { ditujukan } & \text { kepada } & \text { Nabi } \\
\text { Muhammad } & \text { untuk } & \text { tidak } \\
\text { mencampur adukkan akidah }\end{array}$ \\
\hline
\end{tabular}

b. Bermakna Taubikh (التوبخ) atau dan Surat Al-Fajr: 17 dan 18 yang berarti menegur yang seperti pada tabel di bawah ini: terdapat pada Surat Al 'Adiyat: 9,

Tabel 2 Makna Taubikh

\begin{tabular}{|c|c|c|c|}
\hline $\mathrm{NO}$ & Surah \& Ayat & Bermakna & Penejelasan \\
\hline 1. 1 & 1 Al-'Adiyat:9 & 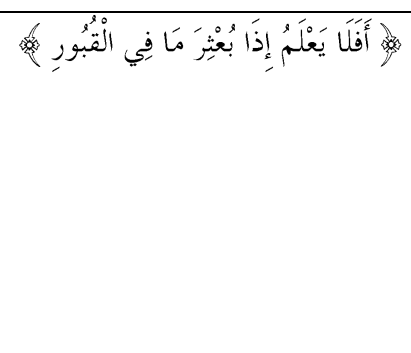 & $\begin{array}{l}\text { teguran Allah S.W.T., } \\
\text { kepada orang-orang yang } \\
\text { selalu sibuk dengan } \\
\text { kehidupan dunia, padahal } \\
\text { manusia akan mati }\end{array}$ \\
\hline 2. & 4 Al-Fajr: 17 & 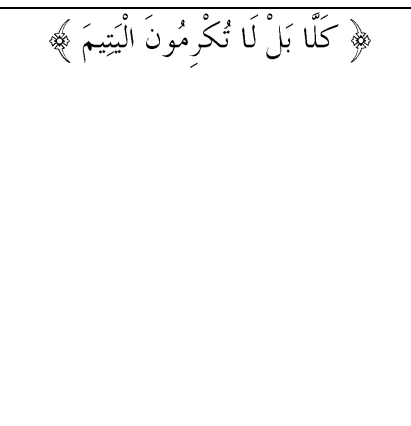 & $\begin{array}{l}\text { teguran Allah terhadap } \\
\text { orang-orang yang } \\
\text { mengeluh atas rizki yang } \\
\text { didapatkan, tetapi lupa } \\
\text { untuk memuliakan anak } \\
\text { yatim }\end{array}$ \\
\hline 3. & 5 Al-Fajr: 18 & 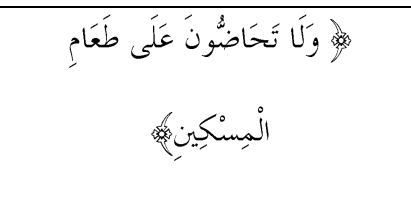 & $\begin{array}{l}\text { teguran Allah S.W.T., } \\
\text { kepada orang-orang yang } \\
\text { tidak mau memeberikan }\end{array}$ \\
\hline
\end{tabular}




\begin{tabular}{|c|c|c|c|}
\hline & & & $\begin{array}{l}\text { makanan kepada orang- } \\
\text { orang miskin }\end{array}$ \\
\hline 4. & Al-Ghasyiyah: 17 & 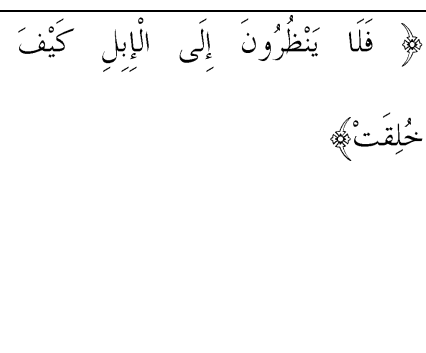 & $\begin{array}{l}\text { teguran Allah S.W.T., } \\
\text { kepada manusia untuk } \\
\text { berpikir } \\
\text { kekuasaan Allah S.W.T., } \\
\text { begitu luas }\end{array}$ \\
\hline
\end{tabular}

c. Bermakna Bayan Al-'Aqabah yang berarti menjelaskan akibar perbuatan sehingga mendapatkan pelarangan seperti pada Surat Al-
Naba: 24(2), 35(2), 37, 38, Al-'Ala: 13(2), Al-Ghasyiyah: 7(2),11, AlFajr: 25, 26, Al-Lail: 15, dan AlMaun: 3

Tabel 3 Makna Bayan Al-'Aqabah

\begin{tabular}{|c|c|c|c|}
\hline NO & Surah \& ayat & Bermakna & Penejelasan \\
\hline 1. & Al-Naba': 24 & 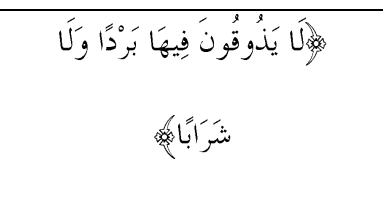 & $\begin{array}{l}\text { akibat perbuatan buruk di dunia, } \\
\text { tidak akan mendepatkan } \\
\text { kesejukan dan minum di neraka }\end{array}$ \\
\hline 2. & Al-Naba': 24 & 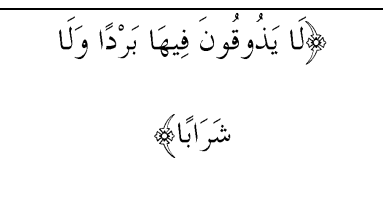 & $\begin{array}{l}\text { akibat perbuatan buruk di dunia, } \\
\text { tidak akan mendepatkan } \\
\text { kesejukan dan minum di neraka }\end{array}$ \\
\hline 3. & Al-Naba': 35 & 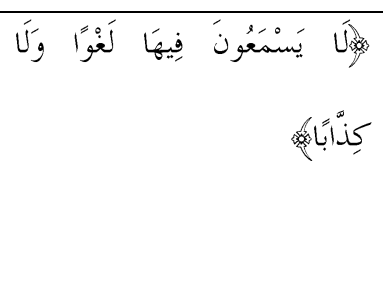 & $\begin{array}{l}\text { orang-orang beriman tidak akan } \\
\text { mendengar perkataan sia-sia dan } \\
\text { dusta di surga karena mereka } \\
\text { melakukan amal saleh }\end{array}$ \\
\hline 4. & Al-Naba': 35 & 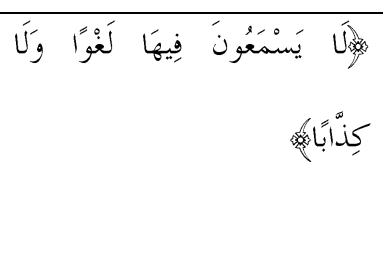 & $\begin{array}{l}\text { orang-orang beriman tidak akan } \\
\text { mendengar perkataan sia-sia dan } \\
\text { dusta di surga karena mereka } \\
\text { melakukan amal saleh }\end{array}$ \\
\hline
\end{tabular}




\begin{tabular}{|c|c|c|c|}
\hline 5. & Al-Naba': 37 & 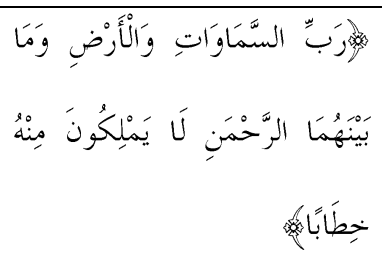 & $\begin{array}{l}\text { semua makhluk dilarang } \\
\text { berbicara, kecuali Allah S.W.T } \\
\text { yang menghendakinya }\end{array}$ \\
\hline 6. & Al-Naba': 38 & 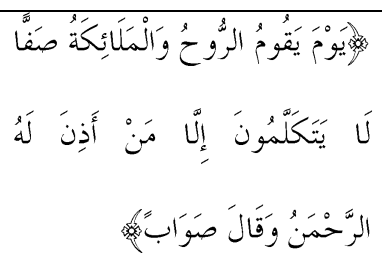 & $\begin{array}{l}\text { semua makhluk dilarang } \\
\text { berbicara, kecuali Allah S.W.T., } \\
\text { yang menghendakinya }\end{array}$ \\
\hline 7. & Al-'Ala: 13 & 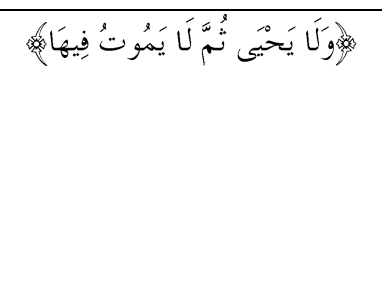 & $\begin{array}{l}\text { orang-orang kafir tidak akan } \\
\text { merasakan mati dan hidup } \\
\text { karena mengingkari Allah } \\
\text { S.W.T., }\end{array}$ \\
\hline 8. & Al-'Ala: 13 & 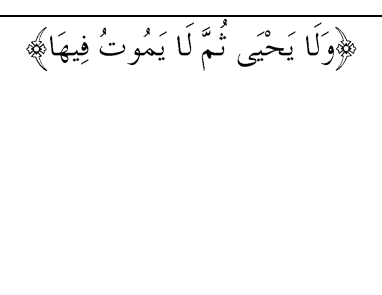 & $\begin{array}{l}\text { orang-orang kafir tidak akan } \\
\text { merasakan mati dan hidup } \\
\text { karena mengingkari Allah } \\
\text { S.W.T., }\end{array}$ \\
\hline 9. & Al-Ghasyiyah: 7 & 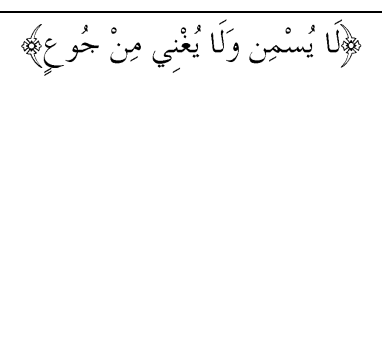 & $\begin{array}{lr}\text { Orang-kafir di neraka } & \text { tidak } \\
\text { mendapatkan makanan } & \text { yang } \\
\text { mengenyangkan lagi } & \text { enak } \\
\text { karena keingkarannya } & \text { kepada } \\
\text { Allah S.W.T., di dunia } & \end{array}$ \\
\hline 10. & Al-Ghasyiyah: 7 & 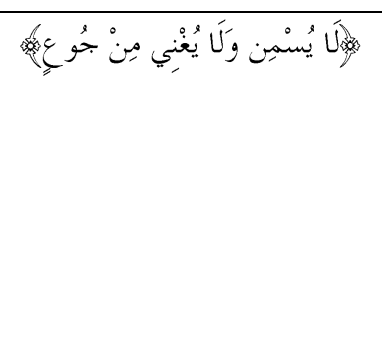 & $\begin{array}{lr}\text { Orang-kafir di neraka } & \text { tidak } \\
\text { mendapatkan makanan } & \text { yang } \\
\text { mengenyangkan lagi } & \text { enak } \\
\text { karena keingkarannya } & \text { kepada } \\
\text { Allah S.W.T., di dunia } & \end{array}$ \\
\hline 11. & Al-Ghasyiyah: 11 & 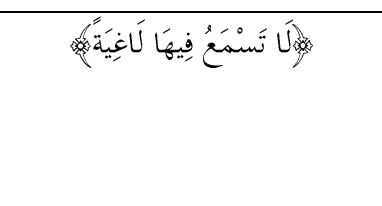 & $\begin{array}{l}\text { bagi orang-orang beriman di } \\
\text { dunia mereka tidak akan } \\
\text { mendengar perkataan yang tidak }\end{array}$ \\
\hline
\end{tabular}




\begin{tabular}{|c|c|c|c|}
\hline & & & berguna \\
\hline 12. & Al-Fajr: 25 & 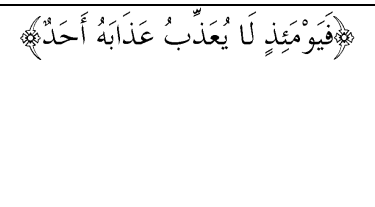 & $\begin{array}{l}\text { tidak akan di azab seseorang } \\
\text { sesuai dengan apa yang telah } \\
\text { dilakukannya di dunia }\end{array}$ \\
\hline 13. & Al-Fajr: 26 & 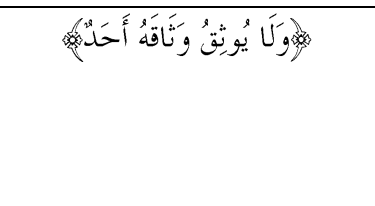 & $\begin{array}{l}\text { tidak akan di azab seseorang } \\
\text { sesuai dengan apa yang telah } \\
\text { dilakukannya di dunia }\end{array}$ \\
\hline 14. & Al-Lail: 15 & 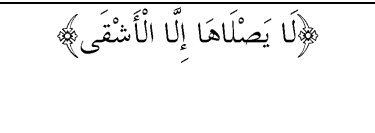 & $\begin{array}{l}\text { dilarang masuk ke neraka } \\
\text { kecuali orang-orang yang celaka }\end{array}$ \\
\hline 15. & Al-Ma'un: 3 & 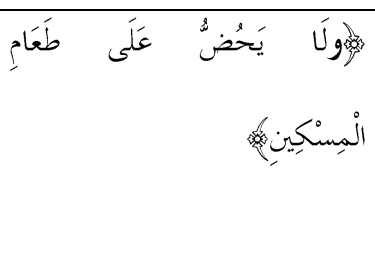 & $\begin{array}{l}\text { orang-orang yang menghardi } \\
\text { anak yatim ialah yang tidak } \\
\text { member makan orang-orang } \\
\text { miskin }\end{array}$ \\
\hline
\end{tabular}

d. Bermakna tais yang berarti menunjukkan putus harapan seperti pada Surat Al-Infithar: 19, sebagaimana firman Allah S.W.T.:

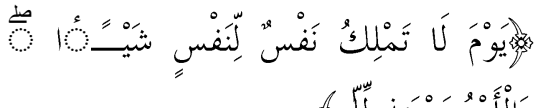

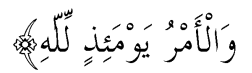

(yaitu) hari (ketika) seseorang tidak berdaya sedikitpun untuk menolong orang lain. dan segala urusan pada hari itu dalam kekuasaan Allah. yakni Allah S.W.T., memberikan gambaran bahwa pada waktu itu mereka tidak bisa menelong diri mereka sendiri ataupn keluarga kerabat, yang bisa menolong diri mereka sendiri adalah Amal di dunia, oleh karena itu Allah S.W.T., menunjukkan keputsasaan manusia bahwa mereka tidak bisa menolong orang lain.

e. Bermakna Dawam yang berarti mempunyai tujuan seperti pada Surat Al-'Ala: 6, dan Al-Syams: 15. 
Tabel 4 Makna Dawam

\begin{tabular}{|c|c|c|c|}
\hline No & Surah \& Ayat & Bermakna & Penejelasan \\
\hline 1 & Al-'Ala: 6 & 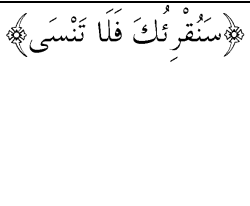 & $\begin{array}{l}\text { Allah Membacakan Al-Qur'an kepeda } \\
\text { Muhammad SA.W., dan jaminannya } \\
\text { tidak akan lupa }\end{array}$ \\
\hline 2 & Al-Syams: 15 & 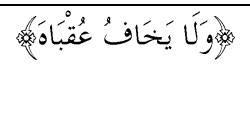 & $\begin{array}{l}\text { Apa-apa yang Allah lakukan tidak akan } \\
\text { pernah takut atas akibatnya }\end{array}$ \\
\hline
\end{tabular}

f. Tahqir (التحقير) menunjukkan makna untuk menghina, seperti pada Surat Al-Balad: 11, sebagaimana firman Allah S.W.T.:

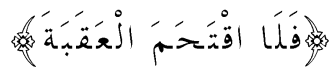

"Tetapi Dia tiada menempuh jalan yang mendaki lagi sukar", Allah S.W.T., menghina orang-orang yang hanya mau jalan yang mudah dalam kehidupannya, padahal jalan yang mendaki dan sukar itu merupakan jalan yang membawa kebahagian dunia dan akhirat.

g. Al-Irshad mempunyai makna yang berarti petunjuk Allah S.W.T., kepada manusia, seperti pada Surat Al-Insyiqaq: 20 dan 21, sebagaimana firman-Nya:

Tabel 5 Makna yang Menunjukkan Al-Irsyad

\begin{tabular}{|c|c|c|c|}
\hline No & Surah dan Ayat & Bermakna & Penejelasan \\
\hline 1 & Al-Insyiqaq: 20 & 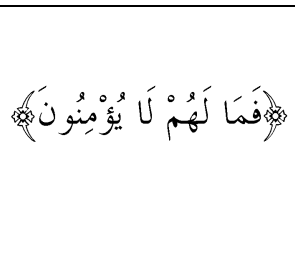 & $\begin{array}{l}\text { Allah memberikan petunjuk kepada } \\
\text { orang-orang yang tidak beriman } \\
\text { kepada Allah dan Rasulnya, dengan } \\
\text { menunjukkan karunia Allah S.W.T., } \\
\text { dalam menciptakan manusia }\end{array}$ \\
\hline 2 & Al-Insyiqaq: 21 & 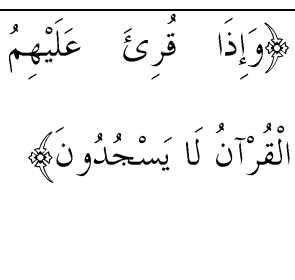 & $\begin{array}{l}\text { Allah S.W.T., memberikan petunjuk } \\
\text { kepada orang-orang yang tidak } \\
\text { beriman kepada Allah dan Rasulnya, } \\
\text { dengan menujukkan keagungan Al- }\end{array}$ \\
\hline
\end{tabular}




\begin{tabular}{|l|l|l|l|}
\hline & & Qur'an yang begitu luar biasa \\
\hline
\end{tabular}

Adapun makn La Nahyu pada juz 30 dapat dilihat pada tabel dibawah ini

Tabel 6 Makna La Nahyu Pada Juz 30

\begin{tabular}{|l|c|c|l|}
\hline Makna & Hakiki & Majazi & total ayat \\
\hline Al-Tahrim & $\checkmark$ & & 4 \\
\hline Taubikh & & $\checkmark$ & 4 \\
\hline Bayan Al-'Aqibah & & $\checkmark$ & 15 \\
\hline Al-Yais & & $\checkmark$ & 1 \\
\hline Dawam & & $\checkmark$ & 2 \\
\hline Tahqir & & $\checkmark$ & 1 \\
\hline Irshad & & $\checkmark$ & 2 \\
\hline Total & & & 29 \\
\hline
\end{tabular}

\section{KESIMPULAN}

Hasil dari penelitian ini ialah bahwa La Nahyu pada Juz 30 terulang29 kali pada Surat An-Naba': 24 (2), 35 (2), 37, 38, Al-Infithar: 19, Al-Insyiqaq: 20, 21, Al-'Ala: 6, 13 (2), Al-Ghasyiyah: 7 (2), 11, 17, Al-Fajr: 17, 18, 25, 26, Al-Balad: 11, As-Syams: 15, Al-Lail: 15, Al-Dhuha: 9,10, Al'Alaq: 19, Al-'Adiyat: 9, Al-Ma'un: 3, Al-Kafirun: 2, dengan kesimpulan bahwa penggunaan kaidah Nahyu Usman Bin sabit yaitu kaidah satu digunakan pada 6 ayat, kaidah empat pada 17 ayat, dan kaidah lima pada 5 ayat, sedangkan makna La Nahyu yang bermakna hakiki terulang 4 kali yang bermakna al-tahrim, sedangkan makna majazi terulang 25 kali dengan makna taubikh 4 kali, bayan al-'aqabah 15 kali, al-yais (اليأس)1 kali, dawam (الدواما) 2 kali, tahqir (التحقير) 1 kali, dan irshad (ارشاد) 2 kali. Hal terebut menunjukkan bahwa ayat-ayat Makiyyah tidak menyinggung masalah hukum syariat tetapi menekankan kepada keimanan, akidah dan moral universal. 


\section{DAFTAR PUSTAKA}

\section{Refrensi dari Jurnal}

Al-Maidaniy, A.H.H. (1996). AlBalagat Al-'Arabiyah: Ususuha wa 'Ulumuha wa Fununuha. Vol. 1, Dar Al-Qalam.

Fahimah, S. (2018). Kaidah-Kaidah Memahami Amr dan Nahy: Urgensitasnya Dalam Memahami Al-Qur'an. Al Furqan: Jurnal Ilmu Al Quran dan Tafsir, 1(1).

Ismardi. (2014). Kaidah-Kaidah Tafsir Berkaitan Dengan Kaidah Ushul Menurut Khalid Utsman Al-Sabt: Kajian Terhadap Kaidah Al-AmmAl-Khass, Al-Mutlaq-AlMuqayyad, dan Al-Mantuq-AlMafhum. Jurnal An-Nida': Jurnal Pemikiran Islam, 39(2).

Kartini. (2016). Penerapan Al-Amr, AlNahy dan Al-Ibahah Sebagai Kaidah Penetapan Hukum. Jurnal $A l-' A d, 9(1)$.

Syamsuri. (2011). Pengantar Qawaid Al-Tafsir." Sulesana, 6(2).

Al-Jami'ah Al-Islamiyyah ibn Allmadinah Al-Nabawi. (t.t.). Mudzakkirah Usul Fiqih. Mauqi' Al-Jami'ah 'ala Iftirafat.

\section{Refrensi dari Buku}

Al-Namlah, Muhammad A.K.A. (1420). Al-Mazhab fi 'Ilmi Usul Fiqhi AlMuqarin. Maktabah Rashada.

Al-Sabt, K.U. (1421). Qawaid AlTafsir. Dar Ibn 'Affan.

Al-Suyuthi, J. (1429). Al-Itqan fii Ulumil Qur'an. 1 ed., Jami AlHuquq Mahfudzat li Nasir.

Hanafie, A. (1981). Usul Fiqh. Jakarta: 8 ed. Widjaya.

Munawwir, A.W. (1997). Al-Munawir. Pustaka Praja.

Mandzur, I. (t.t.). Lisan Al-'Arabiyya. Dar Al-Ma'arif.

Khallaf, A.J. (1991). Kaidah-Kaidah Hukum Islam (Ilmu Ushul Fiqih. Diterjemahkan Noer Iskandar Al'Arsany dan Moh. Tolchah Mansuer. Rajawali Per.

Zuhri dan Chumaidi, A. (1994). Terjemah Jawahirul Balaghah. Surabaya: 1 ed., Mutiara Ilmu.

Al-Karim, A. (2011). Terjemahan AlBalaaghatul Waadhihah. Bandung: 1 ed., Sinar Baru Algensindo.

Bisri, A. dan A. Fatah, M. (1999). Kamus Al-Bisri. Pustaka Progressif.

Yunus, M. (1989). Kamus ArabIndonesia. Mahmud Yunus Wa Dzurriyah. 


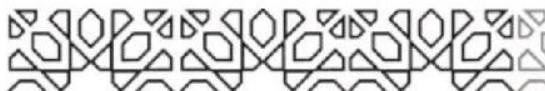 \\ 1.

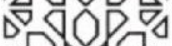

锌

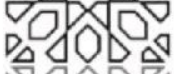

sop

$x$ 